Article

\title{
Interpretation of Mineralization in the Western Carpathians (Polish Segment)_A Tectonic Mélange Approach
}

\author{
Katarzyna Jarmołowicz-Szulc ${ }^{1, *}$ and Leszek Jankowski ${ }^{2}$ \\ 1 Polish Geological Institute, 00-975 Warsaw, Poland \\ 2 Polish Geological Institute, Carpathian Branch, 31-560 Cracow, Poland; leszek.jankowski@pgi.gov.pl \\ * Correspondence: kjar@pgi.gov.pl; Tel.: +48-691745191
}

check for updates

Citation: Jarmołowicz-Szulc, K.;

Jankowski, L. Interpretation of

Mineralization in the Western

Carpathians (Polish Segment) —A

Tectonic Mélange Approach. Minerals

2021, 11, 1171. https://doi.org/

$10.3390 / \min 11111171$

Academic Editor: Chiara Montomoli

Received: 22 August 2021

Accepted: 14 October 2021

Published: 22 October 2021

Publisher's Note: MDPI stays neutral with regard to jurisdictional claims in published maps and institutional affiliations.

Copyright: (c) 2021 by the authors. Licensee MDPI, Basel, Switzerland. This article is an open access article distributed under the terms and conditions of the Creative Commons Attribution (CC BY) license (https:/ / creativecommons.org/licenses/by/ $4.0 /)$.

\begin{abstract}
Quartz, carbonates and other minerals as e.g., realgar are present in veins and caverns in sedimentary rocks in the Western Carpathians. In the Polish segment, they have been characterized from the mineralogical, petrologic, and geochemical points of view, as well as fluid inclusions. Their characters are discussed from perspective of a description of particular types of chaotic complexesthe tectonic mélange zones, distinguished in the Western Carpathian area over the last two decades. The mélange zones are considered to be geochemical systems open to fluid flow, a site for mineral crystallization and/or migration zones of hydrocarbons and mineralized waters. In this context the tectonic mélange in the Jabłonki/Rabe vicinity (SE Poland, the Bieszczady region) in comparison to that of the Mszana Dolna tectonic window area are proposed as the examples. The trapping conditions of fluids (brine and methane) in the minerals in the mélange zones appear to have been $180-205^{\circ} \mathrm{C}$ and $\sim 550-570$ bars, and $220{ }^{\circ} \mathrm{C}$ and 500 bars for calcite and quartz, respectively. The general trend of the increase in temperatures and pressures from west towards east and south-east in the mélange zones points to an increase in the degree of exhumation of different parts of the Carpathians.
\end{abstract}

Keywords: Carpathians; tectonic mélange; mineralization; quartz; calcite; fluid inclusions; mineral waters

\section{Introduction}

The tectonic mélange represents one of the types of chaotic complexes-the sediments which display a lithology of "blocks in the matrix". Numerous mélange zones are present in the Western Carpathians in the south of Poland and contain different minerals. They have been gradually discovered in the field by Jankowski in the last 20 years $([1,2]$, and references therein) and presented on the geological maps of the Carpathians (e.g., [3,4], and references therein). The formation of the mélange zones may be referred to the stages of the tectonic evolution of the Carpathians [5,6]. The tectonic mélange may be deep-rooted and may reach the Carpathian basement related to the pre-Alpian tectonic structures. The main accumulations of the Carpathian hydrocarbons are displayed along the widespread mélange zones in the Carpathians. Recognition of the tectonic mélange zones is, significant for the reconstruction of additional stages of tectonic deformation (strike-slip faults and the orogenic collapse) and for an explanation of mineralization zones, as well as the hydrocarbon migration. Therefore, they should be studied with different methods. Studies of mineralization are one of the important tools. For many years, the relatively rich mineralization present in the Carpathians has been an object of mineralogical and geochemical studies (e.g., [7-10]), with its origin being further related to the mélange zones (e.g., [11-13] and references therein). The present authors believe that there exists a strong correlation between mineral enrichment and the tectonic mélange zones. Mineral occurrences, mostly of quartz and carbonates, are abundant in the tectonic mélange zones or in their aureoles. Different types of fluids that migrate from depth are responsible for the mineralization of rocks and mineral waters $[8,11,13-16]$. 


\section{Geological Setting and Mineralogy}

The Carpathians, which extend for over $1300 \mathrm{~km}$ across Central and Eastern Europe, were formed in the Tertiary by a NE/E-ward migration of an accretionary wedge in front of the Alcapa and Tisza Dacia microplates (e.g., $[17,18])$. This study focuses on the Polish sector of the Outer Carpathians, a thin-skinned thrust and fold belt, which constitutes the accretionary wedge of the Carpathian orogen. The Carpathian orogen is formed of different nappes (tectonic units), as the Magura, Silesia, Dukla and Skole units (Figure 1), which are largely composed of strata from the Lower Cretaceous to the Lower Miocene. The origin of these nappes (oceanic or continental) is still disputed. It is generally accepted that the main stage of primary contractional deformation and thrusting occurred in this region between the Oligocene and the Middle-Late Miocene, and that its direction progressively shifted from NW to NE (e.g., [19-21]).

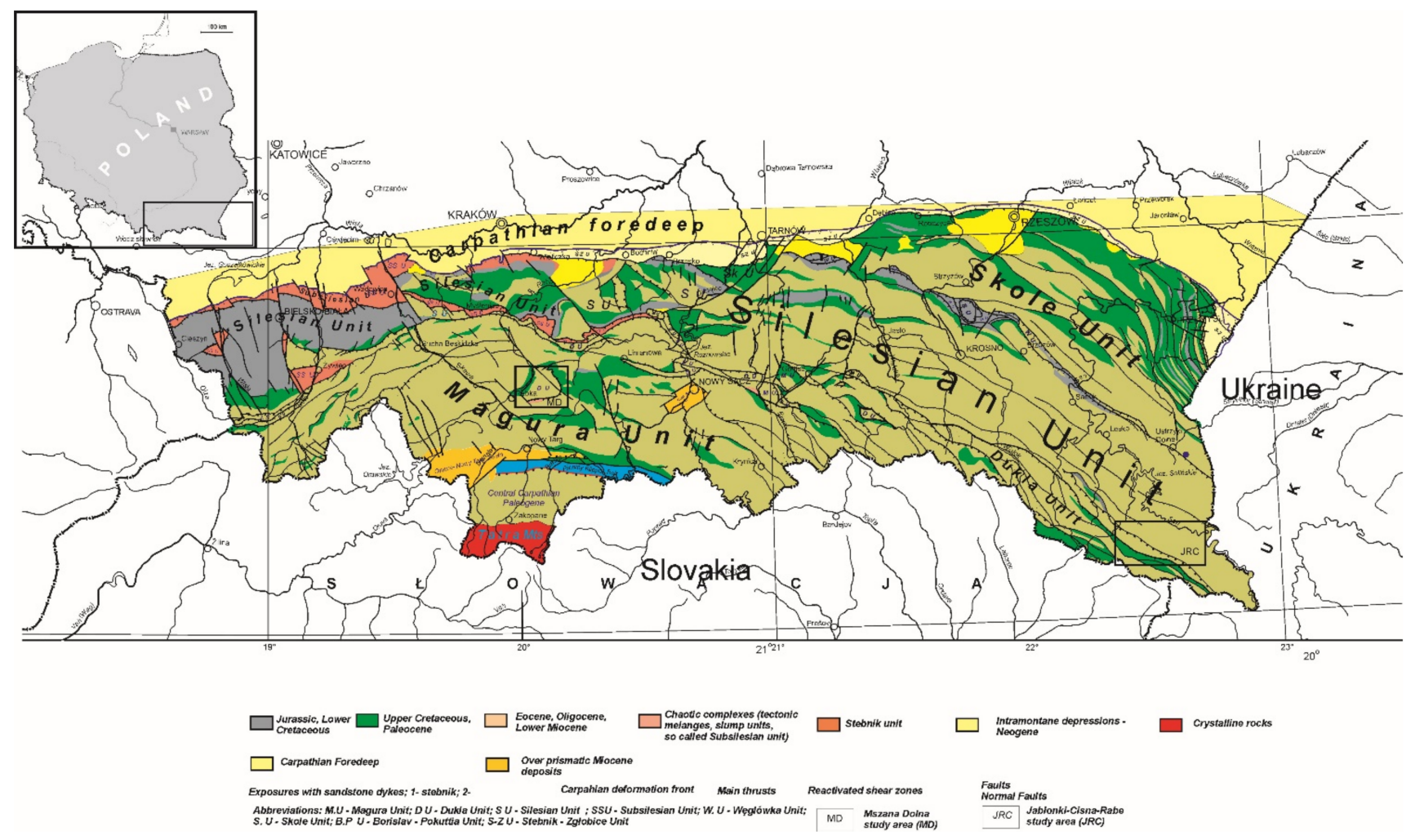

Figure 1. Geological Map of the Outer Carpathians in Poland (after [4], modified).

Several tectonic mélange zones are present in different positions in the Carpathian geometry (Figure 1). The tectonic mélange represents one of the important structures that delineates the main tectonic zones and documents numerous deformation stages, which are primarily connected with the out-of-sequence thrust, gradually re-activated and then enlarged in additional stages of the tectonic deformation (Figure 2). The deposits reach a large width in the outcrops. The process of the enlargement results from the consecutive re-activation of the tectonic zones formed at the primary stage of the formation of the Carpathian orogen. The formation and the orientation of the mélange zones is independent of the orientation of main tectonic units. It postdates the formation of these units. The formation of the mélange zones may be referred to the stages of the tectonic evolution of the Carpathians - the process of strike-slip fault formation, or orogenic collapse $([5,6,22])$. These processes are confirmed by thermochrononometric studies [23]. 


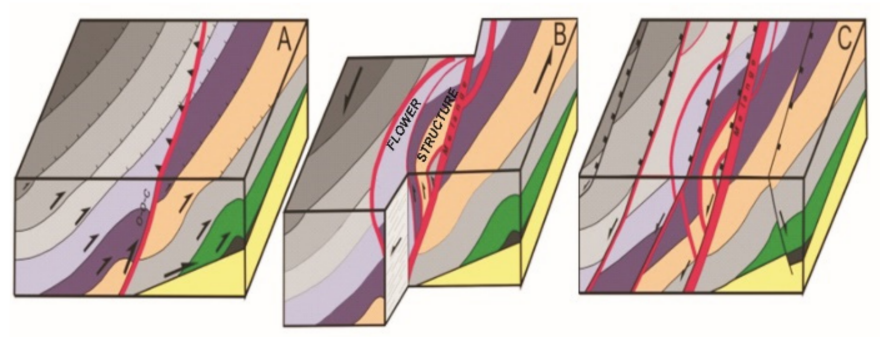

Figure 2. Explanation of formation of tectonic mélange zone. (A) Primary stage with out-of-sequence thrust; (B) Re-activation and formation of flower structure; (C) Final stage-tectonic mélange zone (based on [2]).

The main mélange zone under geological and mineralogical research stretches from the territory of Ukraine (in the East, outside Polish borders) through the Bieszczady region, as it is seen in numerous outcrops in Poland (the area of Jabłonki-Rabe-Cisna (JRC)). The area of the Mszana Dolna tectonic window (MD), where the Dukla unit is exposed tectonically within the Magura unit (Figure 1), has been under present investigation, in some earlier studies, too (e.g., [11,16]). In every localization, the recognized mélange zones are saturated with mineralization. The mineralization processes remain in co-relation with the tectonic deformation of the Carpathians. In general, a filling of the mélange zone with mineralization has been occurring at the post-folding stages during successive stages of tectonic deformation of the Carpathians in the extension regime (strike-strip and collapse stages) from Miocene up to recent times.

The character of fluids in vein minerals has been studied by the authors and referred to fluid migration $[11-13,24]$.

\section{Materials and Methods}

Samples of rocks, minerals and the organic matter were taken for mineralogical, petrologic and geochemical studies from different tectonic mélange zones, in that from two main regions pointed out above. The sampling areas lie in the Polish part of the Western Carpathians and are shown in Figure 1. They are localized in the western part of the mountain chain - near Mszana Dolna (MD) and in the eastern part-near Jabłonki-CisnaRabe (JCR) settlements. For the purpose of the present paper a new sampling was carried out in the MD area, new isotopic analyses performed and fluid inclusion studies were conducted in carbonates. The attempt at an isochore graph interpretation of fluid inclusion results in both study areas is also a new methodic achievement.

The microscopic analyses corresponded to those described elsewhere (e.g., [13], and references therein; [25], and references therein). The procedures comprised several technical and analytical stages (sampling and preparation; microscopic evaluation of the material; detailed microscopic research on inclusions, organic matter and minerals; auxiliary studies, such as CL, Raman or XRD analyses, and stable isotope analyses). In detail, 40 thin sections were petrographically analyzed in the Optiphot 2Pol (Nikon, Warsaw, Poland) polarization microscope. Cathodoluminescence analysis (CL) was performed on all the samples using a CCL $8200 \mathrm{mk}^{3}$ equipment with a cold cathode produced by Cambridge Image Technology Ltd. attached to a Nikon Optiphot microscope. CL observations were used in the analysis of a detrital material and cements, as well as the textural features of the rocks. X-ray analyses were performed using X-ray diffractometer X'Pert PW 3020 by Philips to study the types of minerals (PGI, Warsaw, Poland). Phase analysis was conducted on powder samples (grains to $0.063 \mathrm{~mm}$ ). Diffractograms were registered at angle interval $5^{\circ} \div 60^{\circ} 2 \theta$ and identified based on ICDD tests. Oxygen and carbon isotopic determinations were conducted in Germany, in GeoZentrum Nordbayern at the FriedrichAlexander University Erlangen-Nürnberg for 6 samples in the carbonates. Carbonate powders were reacted with $100 \%$ phosphoric acid at $70{ }^{\circ} \mathrm{C}$ using a Gasbench II connected to a ThermoFisher Delta V Plus mass spectrometer [26]. All values are reported in per mille 
relative to Vienna-Pee Dee Belemnite (V-PDB) (Joachimski, 2020, personal communication [26]). Reproducibility and accuracy were monitored by replicate analysis of laboratory standards calibrated by assigning a $\delta^{13} \mathrm{C}$ of $+1.95 \%$ to NBS19 and $-47.3 \%$ to IAEACO 9 and a $\delta^{18} \mathrm{O}$ of $-2.20 \%$ to NBS19 and $-23.2 \%$ to NBS18. Reproducibility for $\delta^{13} \mathrm{C}$ and $\delta^{18} \mathrm{O}$ was \pm 0.03 and \pm 0.06 ( 1 std. dev., respectively, op. cit.). Fluid inclusion analyses were performed in 30 two-sided-polished wafers. Fluid inclusions were analyzed using a Nikon Linkam freezing-heating stage. Observations were conducted by applying a polarization microscope to both transmitted and reflected lights (UV). Microthermometric analyses were calibrated against melting temperatures of pure chemicals and phase transitions in synthetic fluid inclusions (Synflinc standards). The uncertainty limits of freezing-heating modes are $0.2{ }^{\circ} \mathrm{C}$ below $-100{ }^{\circ} \mathrm{C}, 0.1{ }^{\circ} \mathrm{C}$, between $-100{ }^{\circ} \mathrm{C}$ and $+100{ }^{\circ} \mathrm{C}$, and $1{ }^{\circ} \mathrm{C}$ above $100{ }^{\circ} \mathrm{C}$ until the equipment's temperature threshold. FI petrography was held based on the criteria of $[27,28]$.

Studies on the character of inclusions were conducted using Nikon Eclipse microscope with a fluorescent device. Apart from the so called "inclusion petrography", the inclusions were analyzed in the light of the Mercury lamp in the ultraviolet and blue ranges. The fluorescence of hydrocarbons was induced by ultraviolet reflected light in the plates prepared for fluid inclusion microthermometric studies and observed in the reflected light. Fluid inclusion analyses were performed in carbonates and quartz. Similar analytical steps were carried out. For carbonates, heating conducted was prior to freezing as suggested by [29]. Calculations of microthermometric results (isochores, salinity and other fluid parameters) were conducted using the FLINCOR program [30], which comprises uncomplicated chemical systems. The interpretation of microthermometric results was also performed applying tables by [31]. All calculations were conducted for simplified chemical systems.

Raman analyses performed on new samples were conducted using Thermo Scientific ${ }^{T M}$ DXR equipment at AGH University of Science and Technology, Cracow, Poland with a Nd-YAG laser (wave length of $532 \mathrm{~nm}$ ). Details of measurements are described by [25]. The laser strength was 1-2 $\mathrm{mW}$ for the organic matter, and $5 \mathrm{~mW}$ for fluid and stable inclusions.

\section{Results}

The mélange documented by the authors lies in the Jabłonki-Rabe-Cisna region (the Jabłonki stream) - the JRC area (Figure 1). Further the zone runs through Kołonice, it is well seen in the Rabski stream, turning westwards through Huczwice. It is also outcropped in Kalnica settlement [32]. Sampling proceeded in the distinct mélange zones, as e.g.,: in the vicinity of Jabłonki-Rabe and Cisna (JRC) region in the Bieszczady Mts. [13], and in the west, in the area of the Mszana Dolna tectonic window (MD). Fractured blocks ("block-in-matrix"), clasts and lenses occur in black, schistose rocks in the mélange there. The fractures are filled with mineralization (mostly quartz and carbonates) and bitumen (Figure 3). Other minerals are observed in the field and under the microscope. The rocks were: microsparite limestones with quartz and black aggregates; quartz arenites with a carbonate cement, often with nest aggregates of the coarse crystalline calcite spar; quartz arenites cemented by carbonates and clays, or by quartz-carbonates-clays. The fillings of the veins in the sandstones show yellow-red luminescence for carbonates and violet-blue colors for quartz in CL. 

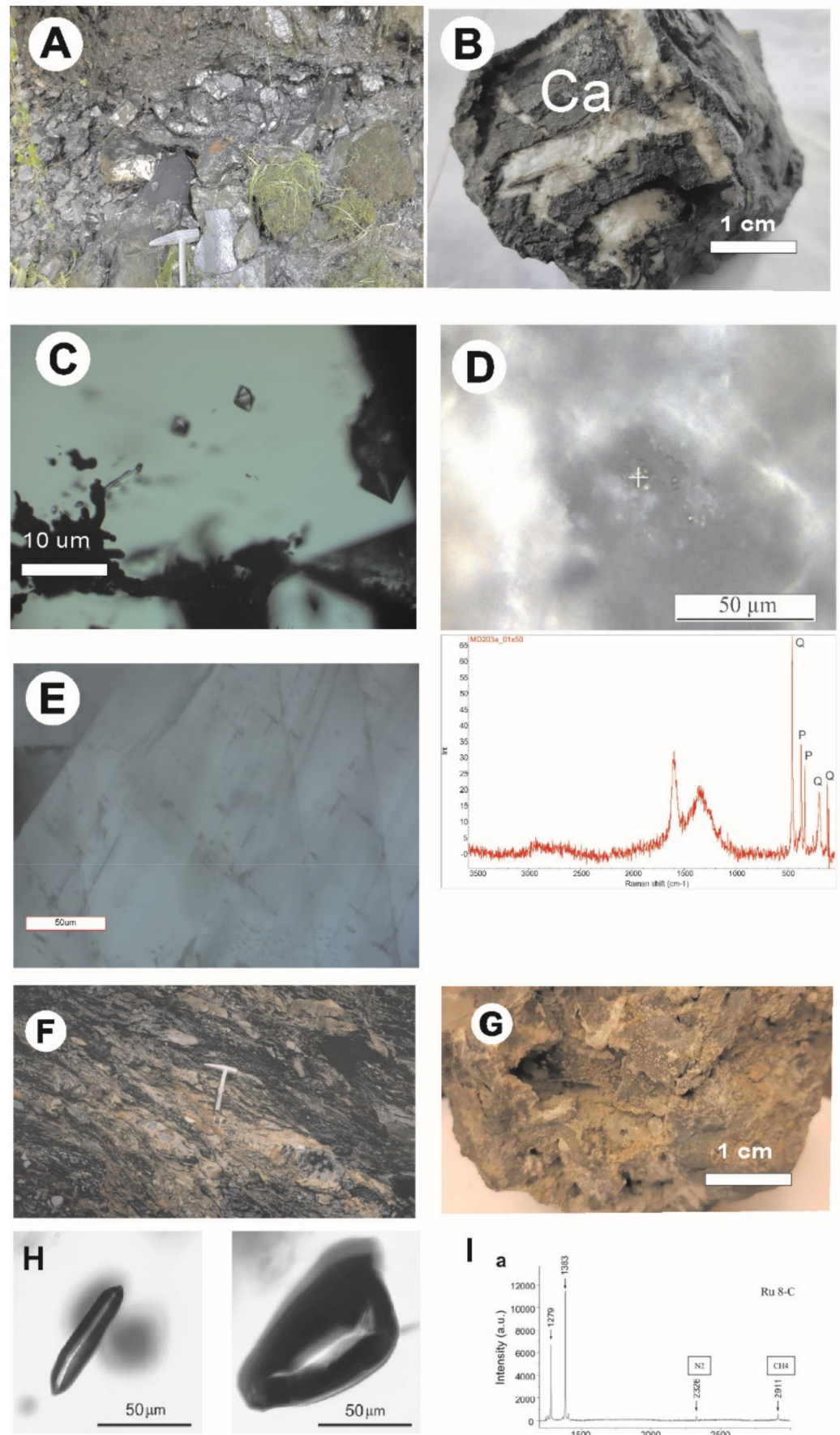

I a
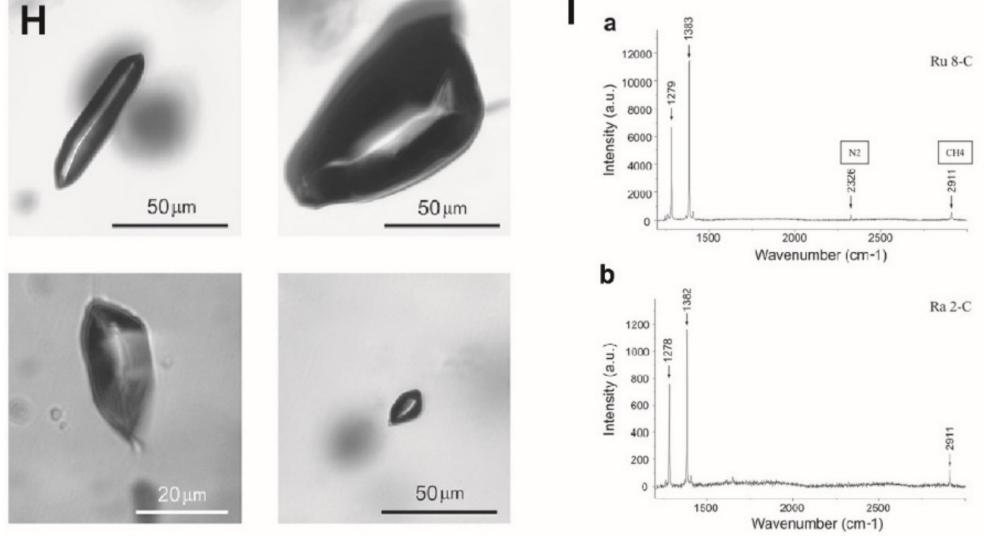

Figure 3. The occurrence of the tectonic mélange in the field and mineralogical samples in MD and JRC areas. (A) The outcrop in the Mszana Dolna region; (B) Calcite veins sampled; (C) Methane inclusions in quartz; (D) Image and Raman spectrum of assemblage of quartz (Q), organic matter and pyrite (P); (E) Fluid inclusions in calcite; (F) The outcrop in the wall of the Jabłonki stream (JRC area); (G) Assemblage of sampled calcite $(\mathrm{Ca})$ and quartz $(\mathrm{Q})$; (H) One phase gas-filled inclusions in quartz; (I) Raman spectra showing presence of methane and nitrogen in inclusions. (a) Ru 8-C, (b) Ra 2-C. 
The organic matter displays no luminescence. The minerals and bitumen infill smaller and larger veins and form aggregates. The SEM chemical composition of these veins points mostly to carbonates, such as calcite, Mn-calcite, dolomite, Mn-dolomite, ankerite, and to pyrite. XRD studies of black organic aggregates in lenses show the presence of quartz, dolomite, calcite, clay minerals, gypsum with anhydrite, feldspars, traces of pyrite and siderite, i.e., a whole fan of minerals. The chemical composition of some carbonate samples in JRC is presented in Table 1, following data from [14]. In the Rabe vicinity (in JRC), other minerals as e.g., realgar are also present, the character of which is shown microscopically in Figure 4. The presence of yellow-red mineralization was noticed in the MD area, this was not sampled, however.

Table 1. XRF analyses of vein calcite (ppm) (from [14]).

\begin{tabular}{cccccccccccc}
\hline Sample & $\mathbf{B a}$ & $\mathbf{C r}$ & $\mathbf{C u}$ & $\mathbf{L a}$ & $\mathbf{M n}$ & $\mathbf{M o}$ & $\mathbf{N i}$ & $\mathbf{S r}$ & $\mathbf{T i}$ & $\mathbf{V}$ & $\mathbf{Z r}$ \\
\hline U1 & $<5$ & 14 & $<5$ & $<5$ & 1207 & $<2$ & 4 & 589 & 84 & $<5$ & 9 \\
PD4 & 99 & 16 & $<5$ & $<5$ & 1163 & $<2$ & 5 & 1304 & 93 & $<5$ & 11 \\
D9 & $<5$ & 15 & $<5$ & $<5$ & 1066 & $<2$ & 5 & 694 & 88 & $<5$ & 5 \\
PD21 & $<5$ & 3 & $<5$ & $<5$ & 704 & $<2$ & $<3$ & 865 & 75 & $<5$ & 6 \\
W13 & $<5$ & 11 & $<5$ & $<5$ & 1102 & $<2$ & 5 & 916 & 80 & $<5$ & 6 \\
PS1 & 487 & 9 & $<5$ & $<5$ & 1078 & $<2$ & 3 & 631 & 143 & 5 & 7 \\
PS2 & $<5$ & 8 & $<5$ & 6 & 1007 & $<2$ & 5 & 773 & 115 & $<5$ & 6 \\
\hline
\end{tabular}
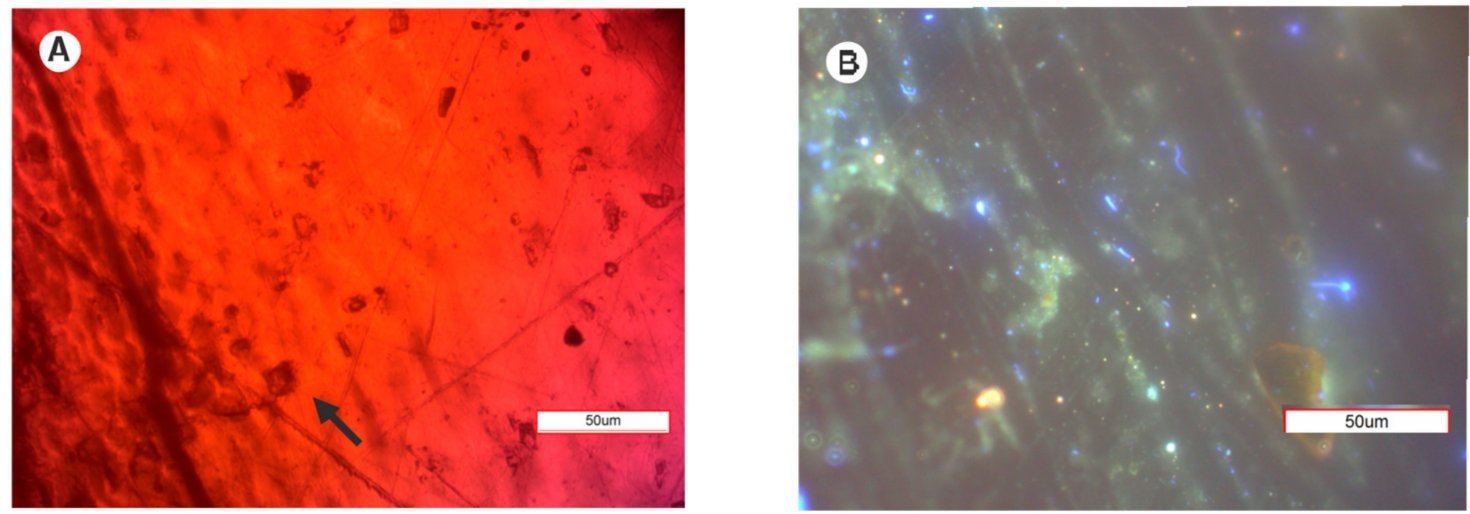

Figure 4. The photomicrograph of realgar within the tectonic mélange in the JRC area (Rabe point). A sample due to the courtesy of T. Wieser [33]. (A) Polarizing microscope image. The arrow points to a bi-phase inclusion. (B) UV image. No characteristic features.

The rocks from the JRC region show a variable values of Total Organic Carbon (TOC-mostly between 0.77 and $4.44 \%$ ), with a low Hydrogen Index (HI), - from 30 to $116 \mathrm{mg} \mathrm{HC} / \mathrm{g}$ TOC). The calcite and quartz fillings contain different hydrocarbon (HCFI) and aqueous (AQFI) inclusions (Figure 3; Figure 3A-E for MD; Figure 3F-I for JRC). One phase, methane filled, inclusions occur in central parts of quartz. In MD they are often broken. They either do not show fluorescence, or are dull-blue. Small, two phase primary aqueous inclusions (AQFI)) in calcite do not fluoresce, the secondary hydrocarbon inclusions (HCFI in fissures cutting cleavage planes) display fluorescence in blue-white colors. The following FI assemblages may be distinguished: primary liquid-gas inclusions filled with brine of low salinity and homogenization temperatures from 150 to $184{ }^{\circ} \mathrm{C}$; primary single-phase inclusions filled with methane that homogenize at temperatures ranging from -75 to $-90{ }^{\circ} \mathrm{C}$ (decrepitation between +85 and $+95^{\circ} \mathrm{C}$ ); primary or secondary (Figure 5) liquid-gas and gas-liquid hydrocarbon inclusions showing white-blue fluorescence; secondary liquid-gas brine inclusions. Microthermometric results are reported elsewhere (e.g., $[7,13,14,24,25,32])$. Table 2 presents some of these data. 
Table 2. Results of fluid inclusion studies in quartz from fissures in the MD and JRC regions.

\begin{tabular}{|c|c|c|c|c|c|c|c|}
\hline Sample ${ }^{1}$ & Locality & Mineral/FI Type & $\begin{array}{c}\text { Ice Melting } \\
\text { Temperature } \mathrm{T}_{\mathrm{m}} \\
\left({ }^{\circ} \mathrm{C}\right)\end{array}$ & $\begin{array}{c}\text { Homogenization } \\
\text { Temperature } T_{h} \\
\left({ }^{\circ} \mathrm{C}\right)^{2}\end{array}$ & $\begin{array}{c}\text { Homogeni } \\
\text { Zation Temperature } T_{h} \\
\left({ }^{\circ} \mathrm{C}\right)^{3}\end{array}$ & $\begin{array}{c}\text { Homogeni } \\
\text { Zation Temperature } T_{h} \\
\left({ }^{\circ} \mathrm{C}\right)^{4}\end{array}$ & $\begin{array}{c}\text { Salinity } \mathrm{NaCl} \\
\text { (wt \% eq.) }\end{array}$ \\
\hline UG-16/08-6 & $\begin{array}{l}\text { Ustrzyki } \\
\text { Górne }\end{array}$ & $\begin{array}{l}\text { Quartz/ } \\
\text { AQFI } \\
\text { HCFI }\end{array}$ & -0.1 & -95.1 & +14.3 & $\begin{array}{l}+117.3 \\
+125.0 \\
+145.3 \\
+146.0 \\
+132.0\end{array}$ & 0.166 \\
\hline MD2/08-1 & Mszana Dolna & $\begin{array}{c}\text { Quartz/ } \\
\text { HCFI }\end{array}$ & & $\begin{array}{l}-82.2 \\
-77.8 \\
-103 \\
-87.5\end{array}$ & $\begin{array}{l}-57.6 \\
-60.0 \\
-56.6\end{array}$ & $\begin{array}{r}+8.5 \\
+16.8 \\
+13.2 \\
+16.0\end{array}$ & \\
\hline MD 2A/08 & Mszana Dolna & $\begin{array}{c}\text { Quartz/ } \\
\text { HCFI }\end{array}$ & & $\begin{array}{l}-103 \\
-87.5\end{array}$ & & & \\
\hline $\mathrm{Ru} 4 / 09$ & Jabłonki & $\begin{array}{c}\text { Quartz/ } \\
\text { HCFI }\end{array}$ & -0.6 & & -61.2 & +128.7 & 0.172 \\
\hline $\mathrm{Ru} 8 / 07$ & Jabłonki & $\begin{array}{l}\text { Quartz/ } \\
\text { AQFI } \\
\text { HCFI }\end{array}$ & $\begin{array}{l}-1.3 \\
-2.1\end{array}$ & -90.7 & -77.4 & $\begin{array}{l}+183.9 \\
+19.2 \\
+22.1\end{array}$ & $\begin{array}{l}2.14 \\
3.49\end{array}$ \\
\hline Ka-13 & Kalnica & $\begin{array}{c}\text { Calcite/ } \\
\text { AQFI }\end{array}$ & -5.6 & -77.4 & & +199.9 & 8.6 \\
\hline $\mathrm{Ra}-1 / 07-1$ & Rabe & $\begin{array}{l}\text { Quartz/ } \\
\text { AQFI } \\
\text { HCFI }\end{array}$ & $\begin{array}{l}-1.1 \\
-1.8\end{array}$ & $\begin{array}{l}-88.8 \\
-88.8\end{array}$ & & +175.9 & $\begin{array}{l}1.80 \\
2.96\end{array}$ \\
\hline Ja $7 / 03^{*}$ & Jabłonki & $\begin{array}{l}\text { Quartz/ } \\
\text { AQFI } \\
\text { HCFI }\end{array}$ & -1.1 & -91.4 & & +173.0 & 1.80 \\
\hline Ja-10* & Jabłonki & $\begin{array}{l}\text { Quartz/ } \\
\text { AQFI } \\
\text { HCFI }\end{array}$ & -1.3 & $\begin{array}{l}-80 \\
-75\end{array}$ & $\begin{array}{l}-58.0 \\
-56.7\end{array}$ & n.d. & \\
\hline
\end{tabular}


Table 2. Cont.

\begin{tabular}{|c|c|c|c|c|c|c|c|}
\hline Sample ${ }^{1}$ & Locality & Mineral/FI Type & $\begin{array}{c}\text { Ice Melting } \\
\text { Temperature } \mathrm{T}_{\mathrm{m}} \\
\left({ }^{\circ} \mathrm{C}\right)\end{array}$ & $\begin{array}{l}\text { Homogenization } \\
\text { Temperature } \mathrm{T}_{\mathrm{h}} \\
\left({ }^{\circ} \mathrm{C}\right)^{2}\end{array}$ & $\begin{array}{c}\text { Homogeni } \\
\text { Zation Temperature } \mathrm{T}_{\mathrm{h}} \\
\left({ }^{\circ} \mathrm{C}\right)^{3}\end{array}$ & $\begin{array}{c}\text { Homogeni } \\
\text { Zation Temperature } \mathrm{T}_{\mathrm{h}} \\
\left({ }^{\circ} \mathrm{C}\right)^{4}\end{array}$ & $\begin{array}{c}\text { Salinity } \mathrm{NaCl} \\
\text { (wt \% eq.) }\end{array}$ \\
\hline B-2002 * & Jabłonki & $\begin{array}{l}\text { Quartz/ } \\
\text { AQFI } \\
\text { HCFI }\end{array}$ & n.d. & $\begin{array}{l}-92.0 \\
-90.0\end{array}$ & & $\begin{array}{l}+150.0 \\
+172\end{array}$ & \\
\hline B-8* & Jabłonki & $\begin{array}{c}\text { Quartz/ } \\
\text { HCFI }\end{array}$ & & $\begin{array}{l}-77.0 \\
-76.6\end{array}$ & & $\begin{array}{l}\text { Decr.+85 } \\
\quad+95\end{array}$ & \\
\hline We 20 & Wetlina & $\begin{array}{c}\text { Quartz/ } \\
\text { HCFI }\end{array}$ & & & & $\begin{array}{l}+79.7 \\
+77.9\end{array}$ & \\
\hline
\end{tabular}

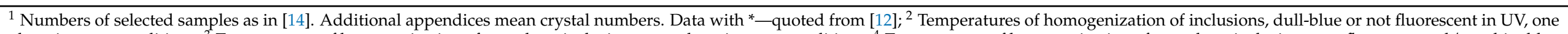

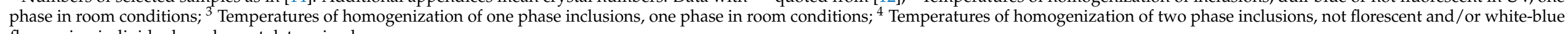
fluorescing individuals. n.d. - not determined. 

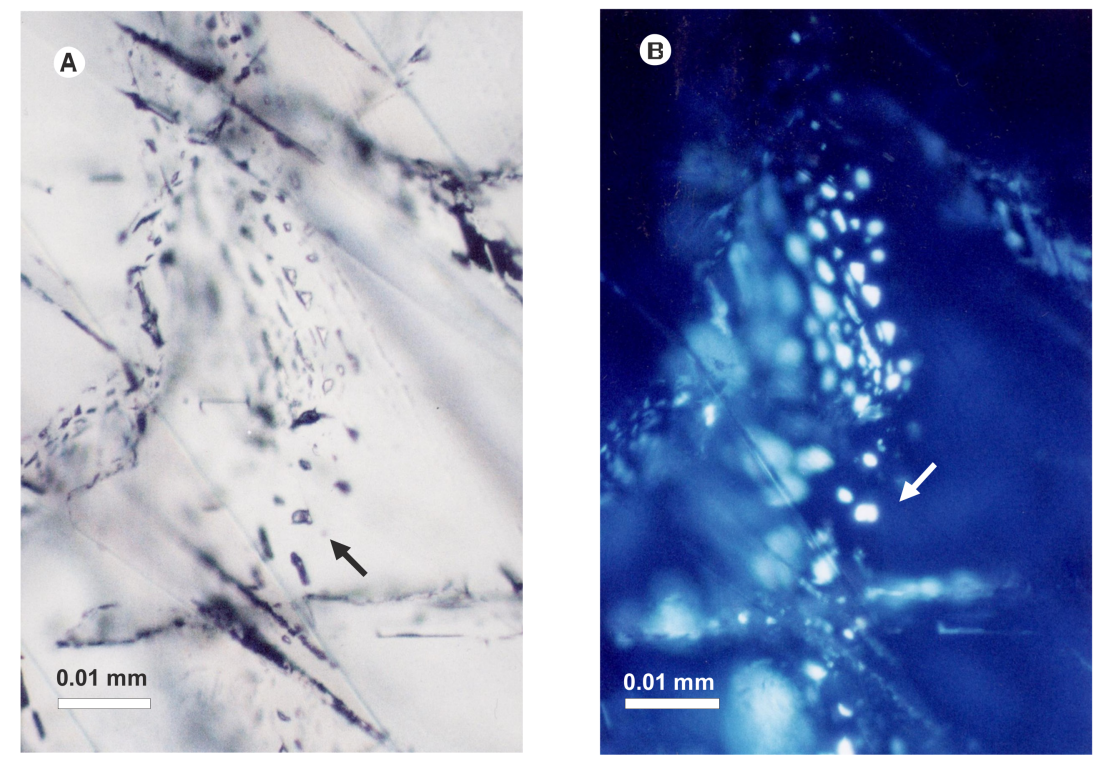

Figure 5. Secondary assemblages of bi-phase fluid inclusions in quartz in the Jabłonki settlement (JRC area). (A) Polarizing microscope, one polarizer, transparent light; (B) Polarizing microscope, UV, reflected light.

The results of recent and earlier stable isotope determinations (presented as $\delta^{13} \mathrm{C}_{\mathrm{VPDB}}$ and $\delta^{18} \mathrm{O}_{\mathrm{VPDB}}$, and $\delta^{13} \mathrm{C}_{\mathrm{PDB}}$ and $\delta^{18} \mathrm{O}_{\mathrm{PDB}}$ values, respectively) for both regions are shown in Table 3 , with recalculation to $\delta^{18} \mathrm{O}_{\mathrm{SMOW}}$, while the regional distribution of data $\left(\delta^{13} \mathrm{C}_{\mathrm{PDB}}\right.$ and $\delta^{18} \mathrm{O}_{\text {SMOW }}$ ) is presented in Figure 6 against the background of other Carpathian regions in Poland, Ukraine and Slovakia.

Table 3. Stable isotope results for vein calcite in JRC and MD.

\begin{tabular}{|c|c|c|c|c|c|}
\hline Sample ID & Locality & Position ** & $\begin{array}{c}\delta^{13} \mathrm{C} \\
\% \text { (PDB) }\end{array}$ & $\begin{array}{c}\delta^{18} \mathrm{O} \\
\% \text { (PDB) }\end{array}$ & $\begin{array}{c}\delta^{18} \mathrm{O}^{*} \\
\% \text { (SMOW) }\end{array}$ \\
\hline \multicolumn{6}{|c|}{ Area: JRC *** } \\
\hline Кa 15/07 & Kalnica, PL & & -0.05 & -8.31 & +22.29 \\
\hline Cisna 3/06 & Cisna, PL & & -0.11 & -7.51 & +23.12 \\
\hline Cisna 10/07 & Cisna, PL & $\begin{array}{l}49^{\circ} 13.383^{\prime \prime} \\
22^{\circ} 21.217^{\prime \prime}\end{array}$ & -0.19 & -6.67 & +23.98 \\
\hline Kalnica 13 & Kalnica, PL & & -1.02 & -8.42 & +22.18 \\
\hline $\mathrm{Ru} 9 / 07$ & Jabłonki, PL & & -2.89 & -9.73 & +20.83 \\
\hline Sample ID & Locality & Position ** & $\begin{array}{c}\delta^{13} \mathrm{C} \\
\% \text { (VPDB) } \\
\pm 0.06\end{array}$ & $\begin{array}{c}\delta^{18} \mathrm{O} \\
\% \text { (VPDB) } \\
\pm 0.03\end{array}$ & $\begin{array}{c}\delta^{18} \mathrm{O}^{*} \\
\% \text { (SMOW) }\end{array}$ \\
\hline \multicolumn{6}{|c|}{ Area: MD } \\
\hline Szcz4/2020 & Szczawa & & -0.07 & -7.99 & +22.62 \\
\hline MD 22/08 & Mszana Dolna region & & -0.90 & -8.97 & +21.61 \\
\hline MD 2/08 & Mszana Dolna region & & -4.53 & -9.44 & +21.13 \\
\hline MD 201/2020 & Mszana Dolna & $\begin{array}{l}49^{\circ} 35.9699^{\prime} \mathrm{N} \\
20^{\circ} 03.87549^{\prime} \mathrm{E}\end{array}$ & -5.38 & -10.85 & +19.68 \\
\hline MD 203A/2020 & Mszana Dolna & $\begin{array}{l}49^{\circ} 40.4229^{\prime} \mathrm{N} \\
20^{\circ} 07.2976^{\prime} \mathrm{E}\end{array}$ & -6.05 & -11.41 & +19.06 \\
\hline
\end{tabular}

${ }^{*}$ Re-calculations according to the $\mathrm{O}^{\prime}$ Neil formula: $\delta^{18} \mathrm{O}(\mathrm{SMOW})=1.03086 \delta^{18} \mathrm{O}(\mathrm{PDB})+30.86$ [34]; ${ }^{* *}$ Exact geographic localization not available in some places; ${ }^{* * *}$ JRC-Sampled between $2007-2010$. 
As shown in the table, $\delta^{13} \mathrm{C}$ values change from -0.05 to $-2.89 \%$ PDB and -0.5 to $-6.05 \%$ PDB, while $\delta^{18} \mathrm{O}$ vary from -6.67 to $-9.73 \%$ PDB in the JRC region and from -7.46 to $-11.41 \%$ (VPDB) in the MD region, respectively.

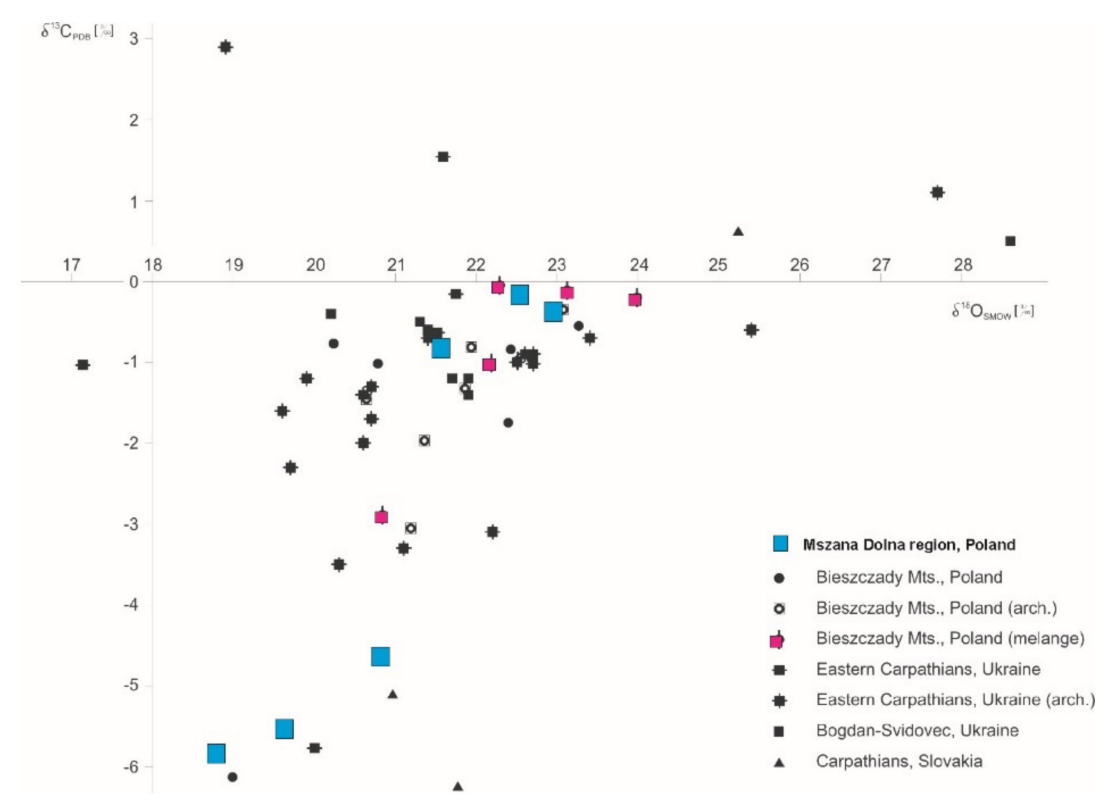

Figure 6. Stable isotope results in the Mszana Dolna area and the Jabłonki-Rabe-Cisna region on the background of data for other parts of the Carpathians (the background after [10]).

\section{Discussion}

The tectonic mélange zones recently distinguished and described by Jankowski $[1,2]$ occur in different localities of the Western Carpathians. The JRC area covers the most significant mélange zone, while the MD area corresponds to the tectonic window outcropping an analogic geological unit. The mélange zones are mostly mineralized in the rocks of the "block-in-matrix" character (Figure 3A). Among the numerous mélange zones the carbonate-quartz mineralization and distinct accumulations of bitumen are predominant [13]. The characteristic feature of the discussed mélange zone (JRC) (Figure 3B) is the occurrence of the carbonate-quartz mineralization with bitumen filling fissures, caverns, and nests, and as veinlets, brushes and accumulations. The veins are filled with quartz, carbonates and bitumen in different spatial relationships. The spatial relations of these components are seen at macroscopic and microscopic scales together with a differentiated chemical composition. Quartz often fills the center part of the vein, being overgrown with bitumen (Figure 3C) and carbonates. In the calcite mass there occur occasionally dolomite crystals. Carbonates display two types- "pure" and with a manganese admixture (e.g., in the JRC region, the manganese dolomite contains from $\sim 0.1$ to $\sim 0.3 \% \mathrm{Mn}$; Table 1 ). The calcite that fills the dolomite (calcite I) is earlier than the bitumen accumulations and the authigenic quartz (the Marmarosh diamond type). Small veinlets prove the occurrence of the earlier crystalline quartz prior to the white calcite. The organic matter (bitumen) described as e.g., asphaltite (MD, [16]), or anthraxolite (JRC, [35]) often fills the central part of the fissures (JRC), or forms impregnations (MD). Quartz and bitumen aggregates were seen in the field, and their presence is also proved at the microscale by Raman spectra and results of microscopic analyses (Figure 3D).

According to [13] in JRC and its neighbourhood, the mélange zone represents the area where the thermal kerogen maturity points to the early "gas window". In the composition of the extractable organic matter, the saturated hydrocarbons constitute a majority ( 61\%), which points to the adsorption of the generated or migrating oil. The quartz crystallizes as fine crystals on the fissure walls and forms distinct authigenic, transparent crystals within the bitumen and/or carbonates. The character of the organic matter oscillates from 
primary, weak mature liptinite material to vitrinite-type substance. The values of the vitrinite reflectance index lie in the interval from 0.96 to $1.54 \%$, while the averages oscillate from 1.0 to $1.43 \%$ (comparewith [14]). The calculated temperatures change from 122 to $191{ }^{\circ} \mathrm{C}$; the averages are between 146 and $182{ }^{\circ} \mathrm{C}$. This is in a real coincidence with the analysis of 33 Raman spectra of the organic matter [25], which point to a temperature of thermal alterations in the interval between $159{ }^{\circ} \mathrm{C}$ and $196{ }^{\circ} \mathrm{C}$ (the Kouketsu et al. method [36]). Similar values were obtained from the homogenization of brine inclusions in the quartz [14]. This is the minimum estimation of temperatures at which the rocks remained in the geological history of the area. These values correspond to the data shown in the bibliography (e.g., [11,14]).

Recent stable isotope data of the carbonate veins (calcite) in MD and earlier results by [14] for JRC point to a diversity of data (Table 2). Their spatial distribution suggests an increase in oxygen analytical results from the west (MD) to the east (JRC), and at least two types of calcite both in MD and JRC confirming the characteristics presented above (Figure 5). These results are compared with the data by $[13,14]$.

Due to the biomarker analysis for saturated and aromatic fractions, pristane/phytane ratios from 1.92 to 2.55 , pristane/C17 ratios from 0.30 to 2.02 and phytane/C18 ratios from 0.15 to 0.73 have been determined $[13,14]$. The source material was deposited in oxygen conditions with bacterial activity. Among pentacyclic terpanes, a peak from oleanane may be distinguished, which suggests a continental component of Tertiary, or younger age within the organic matter trapped in the rock (Matyasik, personal communication [37]). The dimethylophenantrene and methylophenantrene compounds with isomers of the more stable configuration (2-MP and 3-MP) predominate in the distribution of the aromatic fraction. The values of vitrinite reflectance, calculated based on the MPI- 1 factor, evidence a high thermal alteration adequate to $\mathrm{Ro}=1.24 \%$. This corresponds at minimum to a temperature of $\sim 168{ }^{\circ} \mathrm{C}$. Following the discussion from above, the concordance of the independent analytical results of the organic matter dispersed in the rocks and the aromatic fraction of bitumen in the mélange zone may be considered (compare: [14]). It can be concluded that the mélanges in the JRC and MD regions are the evident hydrocarbon migration paths $[14,16]$, which is important from the perspective of hydrocarbon deposits. Hydrocarbons were generated from the terrigeneous organic matter which may correspond to the menilite schists, or to another source.

Hydrocarbons as inclusions are mostly trapped in the "Marmarosh diamonds" (at the late stage of vein/fissure filling), while brine or gas-liquid inclusions are more frequent in calcite. The fluorescent HCFI (Figure 5) prove a presence of higher hydrocarbonspetroleum fluids trapped in minerals, while not fluorescent gas inclusions contain methane with admixture of other components (Figure 3H,I). The solid bitumen in the quartz is occasionally abundant, that results in macroscopically black color of the mineral. It is interesting, that such black crystals are usually long and prismatic. Such crystals were observed both in JRC and in the MD regions. A similar quartz type was also noticed in the Pavlovka vicinity in Ukraine; however, no detailed analysis was conducted [10].

Detailed studies on bitumen-enriched quartz varieties, and other minerals found in the Carpathians (as e.g., realgar, orpiment) may be a future analytical research direction.

Fluids in quartz in AQFI are brines of low composition [13]. The chemical composition of brines in inclusions in calcite is chlorite-sulfide-carbonate. In cases of brine co-occurrence with methane, conditions of co-trapping of these fluids estimated from crossing isochores appear to be in carbonate of $\sim 180-205^{\circ} \mathrm{C}$ and $\sim 550-570$ bars (MD201 sample, MD: AQFI $\mathrm{T}_{\mathrm{h}}=148.5-173.7^{\circ} \mathrm{C}, \mathrm{T}_{\mathrm{m}}=-1.9^{\circ} \mathrm{C}, \mathrm{HCFI}, \mathrm{T}_{\mathrm{h}}=-83.0^{\circ} \mathrm{C}$; Figure $7 \mathrm{a}$ ) and in quartz of $220^{\circ} \mathrm{C}$ and 500 bars (Ra-5 sample, JRC: AQFI $\mathrm{T}_{\mathrm{h}}=180.1^{\circ} \mathrm{C}, \mathrm{T}_{\mathrm{m}}=-6.6{ }^{\circ} \mathrm{C} ; \mathrm{HCFI}, \mathrm{T}_{\mathrm{h}}=-82.6{ }^{\circ} \mathrm{C}$; Figure $7 \mathrm{~b}$ ), assuming that the brine and the methane were trapped simultaneously. For the isochore calculations, equations for not complex chemical systems were used $\left(\mathrm{NaCl}-\mathrm{H}_{2} \mathrm{O}\right.$ and $\mathrm{CH}_{4}$ systems, FLINCOR program [30]). Using this program, isochores for certain pairs of inclusions (AQFI and HCFI) were calculated and adequate lines drawn in the P-T graph. The coordinates of the point at which the isochores cut, represent the trapping conditions. 


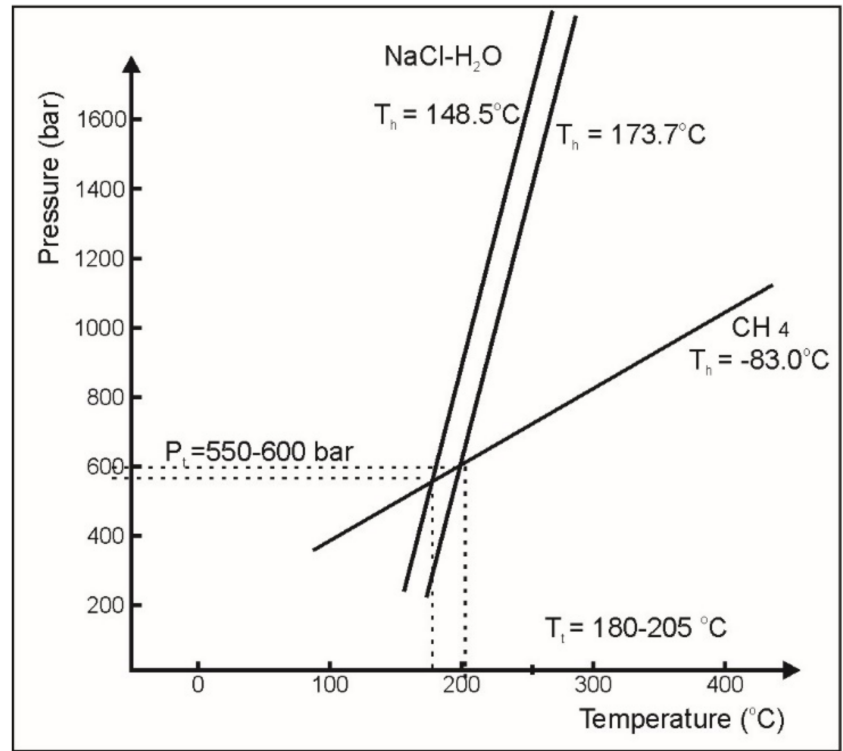

(a)

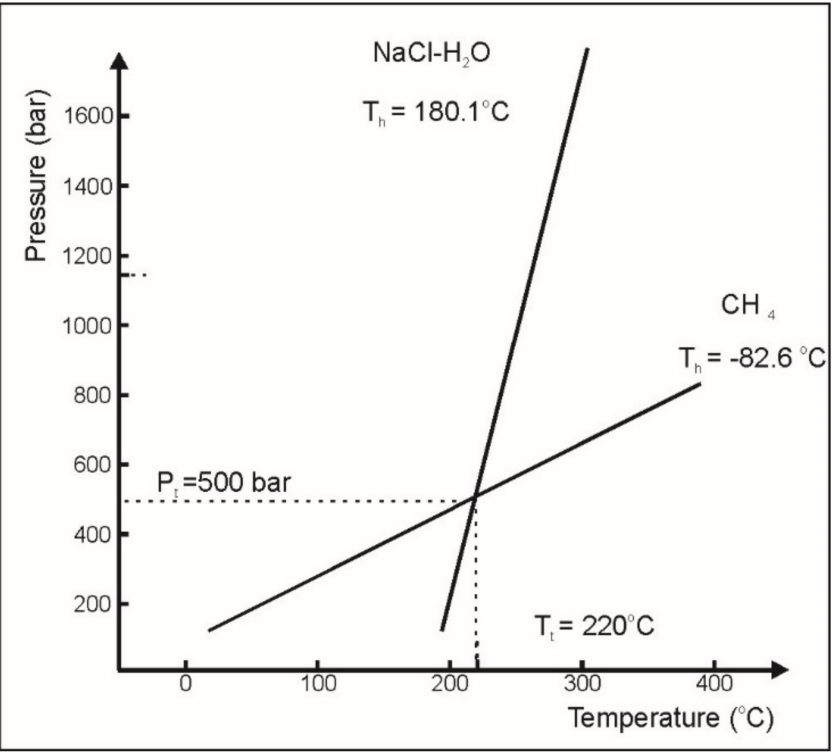

(b)

Figure 7. P-T trapping conditions for brine and methane in inclusions: (a) in carbonate (calcite) in MD, (b) in quartz in JRC. Isochores were calculated using FLINCOR program [30].

In the $\mathrm{MD}$ area, if $\mathrm{T}_{\mathrm{h}}=148.5^{\circ} \mathrm{C}$ for calcite is used to the oxygen isotope diagram (Figure 8 ) in the $\delta^{18} \mathrm{O} \%$ VPDB range between -11.41 and -7.46 (see: Table 2), the isotopic composition of the formation water will correspond to $\delta^{18} \mathrm{O}$ between 5.5 and $9 \%$ sMOW. The isotopic composition of the water for JRC is slightly shifted towards higher positive values $\left(\delta^{18} \mathrm{O}\right.$ of about $7-9 \%$ sMOW). Generally, the isotopic composition of the formation water for MD appears to be lower than that of JRC.

Calcite

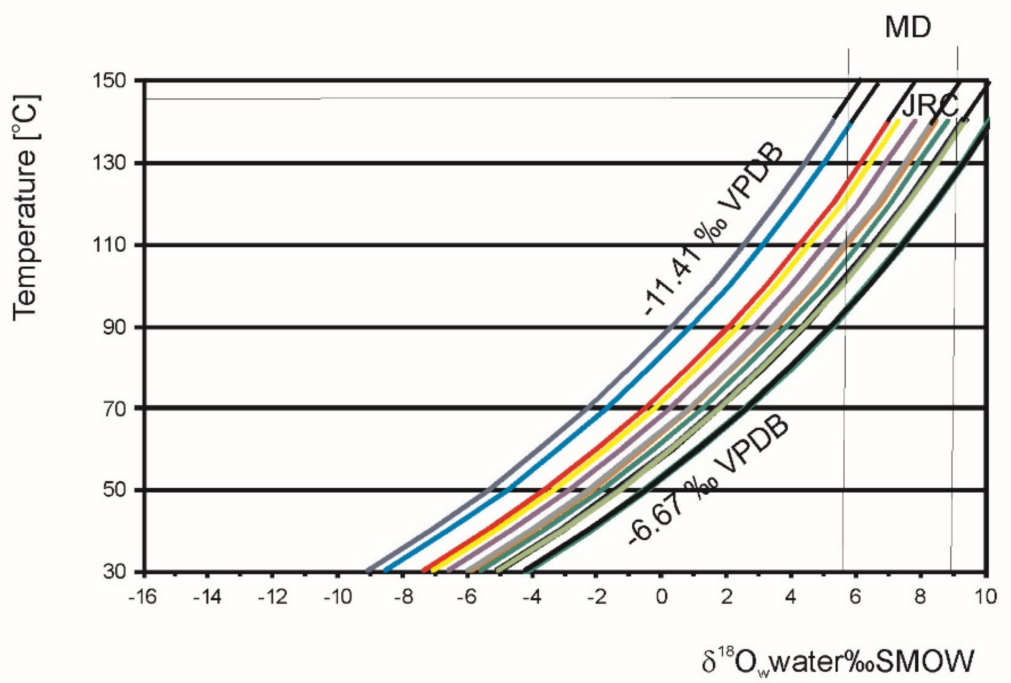

Figure 8. Temperature and $\delta^{18} \mathrm{O}$ relationship for calcite in both regions. Lines were calculated using formula in [38]. MD—range of isotopic values for the MD area; JRC—range of isotopic values for the JRC area. 
The hitherto related, published data on mineralization in the Western Carpathians mostly pertain to quartz (a special type called "the Marmarosh diamonds" - [10,13,14,34,35], less frequently to calcite. This quartz mostly contains brine and hydrocarbon inclusions. In the MD region, the previously cited authors $[34,35]$ estimated fluid pressures of about $0.99 \mathrm{MPa}$ and diversified salinities from 1.5 to 11.5 weight $\% \mathrm{NaCl}$ eq. The earlier estimations point to an interval between 0.49 and $1.3 \mathrm{kbar}$ in the Beskidy Zachodnie area, i.e., the Mszana Dolna region, and to an interval between 0.56 and $2.2 \mathrm{kbar}$ in the Bieszczady Mts., i.e., the Jabłonki-Rabe-Cisna area and further eastwards and south-eastwards. The increase in pressures from the west to the east (toward Ukraine) and the south-east (toward Slovakia) may derived from comparisons of present and bibliographic results in the tectonic mélange context. That is summarized in Table 4 with the generalized results from Ukraine and Slovakia.

Table 4. Variation in temperature, pressure and brine salinity in the area of the Polish part of the Carpathians and outside Polish frontiers.

\begin{tabular}{ccccc}
\hline Characteristics & Beskidy Zachodnie * & Bieszczady * & $\begin{array}{c}\text { Eastern and } \\
\text { South-Eastern Directions }\end{array}$ & References \\
\hline Temperature $\left({ }^{\circ} \mathrm{C}\right)$ & $75-137$ & $116-196$ & $110-230$ & {$[7,10,25,39,40]$} \\
& $\rightarrow$ & $\rightarrow$ & $0.5-2.7$ \\
Pressure (kbar) & $0.49-1.3$ & $0.56-2.2$ & Stavne-Volovec (Ukraine) \\
& Mszana Dln about & Rabe-Wołosate & $0.8-1.5$ & Dara (Slovakia) \\
& 0.99 MPa & $\rightarrow$ & $1.65-2.06$ & \\
\hline Brine salinity & $\rightarrow$ & $4-14$ & & \\
\hline
\end{tabular}

* Arrows $(\rightarrow)$ suggest a general trend of an increase in values from the west towards east and south-east.

The observed trend of increasing temperature-pressure values of minerals from the west to the east and south-east may be a result of the tectonic relations of the areas. This suggests differences in the exhumation of the particular regions (the mélange zones) from the west eastwards and south-eastwards. The deep-rooted mélange zone in the east (i.e., the JRC region) could have been deeper than that in the west (i.e., the MD region). Additionally, the presence of minerals such as realgar or orpiment may suggest that the mélange's foundation is on the boundaries of huge blocks in the Carpathian basement.

The thermal and mineralized waters in the Outer Carpathians occur both in the flysch formation and in the underlying rocks. The complicated geological structure is the cause that the waters are recognized in privileged zones, related mostly to the tectonic zones. They may also be concerned as fluids expelled tectonically (compare with [15]). The present paper's authors are of the opinion that the origin of these waters should be referred to the mélange. In the vicinity of the JRC mélange zone described above, the mineralized waters occur in the Rabe and Polańczyk settlements. The waters there are highly mineralized and display the following chemical composition: $0.2-0.3 \% \mathrm{HCO}_{3}-\mathrm{Cl}-\mathrm{Ca}, \mathrm{CO}_{2}$ (Rabe) and $0.24 \mathrm{HCO}_{3}-\mathrm{Na}$ (Polańczyk IG-1) and 0.89\% Cl- $\mathrm{HCO}_{3}-\mathrm{Na}$ (Polańczyk IG-2), showing weak or no reproducing ability. It seems that the flysch is a low prospective collector for the thermal waters $[42,43]$. The zone of conditions prospective for mineral waters appears to be present in the Rabka-Zdrój and Poręba Wielka, that is exactly in the area of the MD tectonic window. The water parameters there are: up to $16.1 \mathrm{~m}^{3} / \mathrm{h}$ water with mineralization of $24-28 \mathrm{~g} / \mathrm{dm}^{3}$ and of temperature of $28-42{ }^{\circ} \mathrm{C}$ at the outlet (the Rabka IG-2 and Poreba IG-1 wells). If we compare the composition of brines in FI in carbonates in the MD area (chlorate-sulfide-carbonate composition) with the chemical character of mineral waters in the neighborhood, it seems that they really may be related. However, the relationship between mineralization and mineral waters in the tectonic zones demands detailed analyses, and this will be a further research direction. 


\section{Conclusions}

The following conclusions may be drawn from the combined geological and mineralogical research:

- The tectonic mélange zones occur in different localities of the Western Carpathians;

- The mineralization in the mélange zones occurs in veins and accumulations in the rocks of the "block-in-matrix" character;

- The veins are mostly filled with quartz, carbonates and bitumen in different spatial relationship with the presence of other minerals (e.g., realgar, orpiment, pyrite);

- The deep rooting of the mélange zones enables fluid migration from the relatively high depth of the Carpathians, even from their basement;

- The mélange zones represent open geochemical systems which enable both hydrocarbon (in that-also oil seepages) and mineral water migration;

- The mélange zones represent one of the most significant elements of the Carpathian hydrocarbon system;

- Tectonically expelled fluids are responsible both for the mineralization of the rocks and for mineral waters;

- The trapping conditions of fluids (brine and methane) in the minerals in the present studied mélange zones appear to have been of $180-205^{\circ} \mathrm{C}$ and $\sim 550-570$ bars (in MD) and $220^{\circ} \mathrm{C}$ and 500 bars (in JRC) for calcite and quartz, respectively;

- A general trend of increasing temperatures and pressures from $\mathrm{W}$ to $\mathrm{E}$ and SE may be observed which suggests different degrees of exhumation of the mélange zones;

- The deep-rooted mélange zone in the east (e.g., the JRC region) appears to have been deeper than that in the west (e.g., the MD region);

- The repeating processes of mineralization are connected with the re-opening of the adequate systems as a result of the orogenic collapse events.

Author Contributions: Conceptualization, K.J.-S. and L.J.; methodology, K.J.-S.; validation, K.J.S. and L.J.; formal analysis, K.J.-S.; investigation, K.J.-S.; field works, L.J.; writing-original draft preparation, K.J.-S.; writing—review and editing, K.J.-S.; visualization, K.J.-S. and L.J.; supervision, K.J.-S.; project administration, K.J.-S. All authors have read and agreed to the published version of the manuscript.

Funding: The paper has been supported by the Polish Ministry of Science and Higher Education (PGI-NRI grant No. 62.9012.2036.00.0).

Acknowledgments: The authors acknowledge the presence of Adam Kozłowski in the newest sampling, during pandemic. Michael Joachimski is thanked for last stable isotope determinations. The authors thank Wanda Narkiewicz for XRD analyses. Pete Modreski is thanked for his language corrections. Cordial thanks are also addressed to anonymous reviewers for their reviews, critical comments and suggestions of manuscript correction.

Conflicts of Interest: The authors declare no conflict of interest.

\section{References}

1. Jankowski, L. Geological Structure of the Area between Łużna and Stróże; AGH: Krakow, Poland, 1995. (In Polish)

2. Jankowski, L. A new look at the geological structure of the Carpathians-A discussion. In Prace Naukowe Instytutu Nafty $i$ Gazu—PIB; Instytut Nafty i Gazu, Państwowy Instytut Badawczy: Kraków, Poland, 2015; Volume 202, ISSN 2353-2718. (In Polish)

3. Jankowski, L.; Jarmołowicz-Szulc, K.; Matyasik, I. Geological and cartographic studies as the basement for mineralogical, geochemical and petrographic analyses. Prz. Geol. 2007, 55, 290.

4. Jankowski, L. Detailed Geological Map of Poland at Scale1:50,000, Łupków Nowy Sheet; PIG—PIB: Warszawa, Poland, 2015.

5. Mazzoli, S.; Jankowski, L.; Szaniawski, R.; Zattin, M. Low-T thermochronometric evidence for post-thrusting ( $<11$ Ma) exhumation in the Western Outer Carpathians, Poland. Comptes Rendus Geosci. 2010, 342, 162-169.

6. Jankowski, L.; Probulski, J. The tectonic and basin development of the Outer Carpathians on the example of the geological structure of the Grabownica, Strachocina and Łodyna fields and the vicinity. Geol. Geophys. Environ. 2011, 37, 555-583.

7. Dudok, I.V.; Jarmołowicz-Szulc, K. Vein minerals in Polish and Ukrainian Carpathians. Prz. Geol. 2001, 48, 341-342.

8. Jarmołowicz-Szulc, K. Characteristic features of the vein formation in SE part of the Polish Carpathians. Geol. Carpathica 2002, 53, 4 . 
9. Jarmołowicz-Szulc, K. Studies on quartz as the tracer of fluid migration. In Proceedings of the International Congress of Applied Mineralogy-ICAM 2004, ICAM, Aguas de Lindoia, Brazil, 19-22 September 2004.

10. Jarmołowicz-Szulc, K.; Dudok, I.V. Migration of palaeofluids in the contact zone between the Dukla and Silesian units, Western Carpathians-Evidence from fluid inclusions and stable isotopes in quartz and calcite. Geol. Quart. 2005, 49, $291-304$.

11. Jarmołowicz-Szulc, K. A mineralogical and geochemical contribution to the studies on problematics of fluid flows in the Carpathians. Min. Rev. 2009, 59, 42-55.

12. Jankowski, L.; Jarmołowicz-Szulc, K. Particular tectonic zones (the mélange zones) as a potential and significant path for fluid migration and mineral formation. Min. Rev. 2009, 59, 31-44.

13. Jarmołowicz-Szulc, K.; Jankowski, L. Geochemical analysis and genetic correlations for bitumen and rocks of the black shale types in the outer Carpathian tectonic units in southeastern Poland and the adjacent territory. Biul. Państw. Inst. Geol. 2011, 444, 73-98.

14. Jarmołowicz-Szulc, K.; Karwowski, Ł.; Marynowski, L. Fluid circulation and formation of minerals and bitumen in the sedimentary rocks of the Outer Carpathians-Based on studies on the quartz -calcite- organic matter association. Mar. Petr. Geol. J. 2012, 32, 138-158. [CrossRef]

15. Jarmołowicz-Szulc, K. Fluids expelled tectonically and their significance in hydrocarbon migration. Int. J. Pet. Petrochem. Eng. 2017, 3, 1-6. [CrossRef]

16. Karwowski, Ł.; Dorda, J. Mineral-Forming environment of "the Marmarosh diamonds". Mineral. Pol. 1986, 17, 3-12.

17. Nemčok, M.; Pospíšil, L.; Lexa, J.; Donelick, R.A. Tertiary subduction and slab breakoff model of the Carpathian-Pannonian region. Tectonophysics 1998, 295, 307-340. [CrossRef]

18. Sperner, B.; Ratschbacher, L.; Nemčok, M. Interplay between subduction retreat and lateral extrusion: Tectonics of the Western Carpathians. Tectonics 2002, 21, 1051. [CrossRef]

19. Nemčok, M.; Pospišil, L.; Hrušecky, I.; Zsìros, T. Subduction in the remnant Carpathian flysch basin. AAPG Mem. 2006, 767-778. [CrossRef]

20. Jankowski, L.; Kopciowski, R.; Ryłko, W. Geological Map of the Outer Carpathians: Borderlands of Poland, Ukraine and Slovakia, 1:200.000; Polish Geological Institute: Warszawa, Poland, 2007.

21. Jankowski, L. Chaotic complexes in the Gorlice region (Polish Outer Carpathians ). Biul. Państwowego Inst. Geol. 2004, 426, 27-52.

22. Jankowski, L.; Margielewski, W. Geological control of the Outer Western Carpathians' relief formation: From basinal stage to gravitational collapse-A new approach. In Proceedings of the Book and Abstracts of 4th Central European Geomorphology Conference, Bayeruth, Germany, 9-13 October 2017; Holzheu, S., Thies, B., Eds.; University of Bayeruth: Bayeruth, Germany; Volume 120, pp. 21-22.

23. Andreucci, B.; Castelluccio, A.; Jankowski, L.; Mazzoli, S.; Szaniawski, R.; Zattin, M. Burial and exhumation history of the Polish Outer Carpathians: Discriminating the role of thrusting and post-thrusting extension. Tectonophysics 2013, 608, 866-883. [CrossRef]

24. Jarmołowicz-Szulc, K.; Jankowski, L.; Matyasik, I. Preliminary results of the studies of mineral assemblages and the organic matter in the Bieszczady region. Prz. Geol. 2007, 55, 291.

25. Jarmołowicz-Szulc, K.; Toboła, T. Microthermometric and Raman spectra studies in minerals in the Rabe vicinity (Carpathians) An experimental practice. Prz. Geol. 2021, 69, 361-364.

26. Joachimski, M.; (Friedrich-Alexander University Erlangen-Nürnberg, Erlangen, Germany). Personal Communication, 2020.

27. Roedder, E. Reviews in Mineralogy, Fluid Inclusions. Miner. Soc. Am. 1984, 12, 1-254.

28. Goldstein, R.H.; Anderson, A.; Marshall, D. Petrographic analysis of fluid inclusions. Fluid Incl. Anal. Interpret. $2003,32,9-54$.

29. Goldstein, R.H.; Reynolds, T.J. Systematics of fluid inclusions in diagenetic minerals. SEPM Short Course 1994, 31, 199.

30. Brown, P.E. FLINCOR: A microcomputer program for the reduction and investigation of fluid inclusion data. Am. Min. 1989, 74, 1390-1393.

31. Bodnar, R.J.; Samson, I.; Anderson, A.; Marshall, D. Interpretation of data from aqueous-electrolyte fluid inclusions. Fluid Incl. 2003, 32, 81-101.

32. Jankowski, L.; Jarmołowicz-Szulc, K. The preliminary mineralogical characteristic of the tectonic mélange in the Bieszczady Mts. In Proceedings of the Search on Hydrocarbons as the Source of Innovation in Recognition of Geological Structure of the Carpathians, the Carpathian Foredeep and Their Basement. LXXV Scientific Conference PTG, Iwonicz-Zdrój, Poland, 22-25 September 2004; Conference Materials, 122. Państwowy Instytut Geologiczny: Cracow, Poland, 2004. (In Polish)

33. Wieser, T.; (PGI: Cracow, Poland). Sampling in the Rabe Region and Personal Communication, 2001.

34. O'Neil, J.R. Stable isotope geochemistry of rocks and minerals. In Lectures in Isotope Geology; Jaeger, E., Hunziker, J.C., Eds.; Springer: Berlin, Germany, 1979; pp. 235-263.

35. Dudok, I.V.; Kotarba, M.; Jarmołowicz-Szulc, K. Employment of pyrolitic methods in geochemical studies of organic matter of the vein formations in the flysch of the Carpathians Mts. Geol. Geochim. Goriuchih Kopalin 2002, 1, 76-87. (In Ukrainian)

36. Kouketsu, Y.; Mizukami, T.; Mori, H.; Endo, S.; Aoya, M.; Hara, H.; Nakamura, D.; Wallis, S. A new approach to develop the Raman carbonaceous material geothermometer for low-grade metamorphism using peak width. Island Arc. 2014, $23,33-50$. [CrossRef]

37. Matyasik, I. (Institute for Oil and Gas: Cracow, Poland). Personal Communication, 2010.

38. Friedman, I.; O'Neil, J. Compilation of stable isotope fractionation factors of geochemical interest. In Data of Geochemistry; Fleischer, M., Ed.; U.S. Geological Survey: Liston, VA, USA, 1977; Volume 440-K, pp. 1-12. 
39. Kozłowski, A.; Metz, P.; Młynarczyk, M. Crystallization conditions of Marmarosh diamonds from the Carpathian flysch, as indicated by fluid inclusion studies. In Proceedings of the Jahrestagung der Deutschen Mineralogischen Gesellschaft, Kiel, Germany, 9-12 September 1996. Berichte der Deutschen Mineralogischen Gesellschaft-Nachtrag von Kurzreferaten.

40. Świerczewska, A.; Hurai, V.; Tokarski, A.K.; Kopciowski, R. Quartz mineralization in the Magura nappe (Poland): A combined microstructural and microthermometry approach. Geol. Carpath 1999, 50, 174-177.

41. Hurai, V.; Kihle, J.; Kotulova, J.; Marko, F.; Świerczewska, A. Origin of methane in quartz from the Tertiary accretional wedge and forearc basin of the Western Carpathians. Appl. Geochem. 2002, 17, 1259-1271. [CrossRef]

42. Zuber, A.; Chowaniec, J. Diagenetic and other highly mineralized waters in the Polish Carpathians. Appl. Geochem. 2009, 24, 1899-1900. [CrossRef]

43. Hajto, M. Characteristics of main hydrothermal structures prospective for binary technologies. In Atlas of the Possible Use of Geothermal Wares for Combined Production of Electricity and Heat Using Binary Systems in Poland; Bujakowski, W., Tomaszewska, B.E., Eds.; IGSMiE PAN: Cracow, Poland, 2014; pp. 25-74, ISBN 978-836-2922-33-8. (In Polish) 